\title{
THE PATHOLOGY OF TRIBAL NATIONALISM ACCORDING TO HANNAH ARENDT UNCOVERING RELIGIOUS POPULISM MECHANISMS WHICH JEOPARDIZE CULTURAL DIVERSITY
}

\author{
* Johannes Haryatmoko \\ Lecturer in Philosophy at the Sanata Dharma University Yogyakarta \\ Submitted: 13-11-2018; Revised:12-01-2019; Accepted: 13-02-2019
}

\begin{abstract}
ABSTRAK
Fenomena populisme agama yang marak di banyak negara di dunia telah mempengaruhi situasi sosial-politik di Indonesia, terutama sepuluh tahun terakhir ini. Para penganut populisme agama mengusung propaganda penilaian moral dalam bentuk mengutuk korupsi, kemunduran moral, dan elite penguasa busuk. Mereka menggambarkan masyarakat dalam kerangka Manichean seakan hanya ada dua kelompok yang saling bertentangan: yang baik atau "kita" dan yang jahat "mereka". Dengan mendefinisikan masyarakat dalam dua kategori itu, mereka mau menekankan pentingnya peran identitas agama supaya dengan demikian memudahkan untuk mengelompokkan ke kedua kategori tersebut. Hannah Arendt menawarkan alat analisis yang memungkinkan untuk menyingkap mekanismemekanisme populisme agama. Sasaran utama analisisnya bertolak dari pathologi "nasionalisme tribal". Hasil analisisnya membantu untuk memeriksa kesamaan-kesamaan antara "nasionalisme tribal" dengan fenomena populisme agama. Ketajaman analisis Hannah Arendt ini tentu berkat pengalaman pribadinya menderita persekusi pada era-Nazi dan penelitiannya yang mendalam dari arsip-arsip yang handal. Dengan menggunakan metode perbandingan dan kritis, dapat disimpulkan bahwa patologi nasionalisme tribal memberi pelajaran bagaimana gerakan populis semacam itu tidak bisa menerima perbedaan dan cenderung menjadi totalitarian. Membandingkan dua fenomena itu membuka perspektif baru dalam menjelaskan fenomena propaganda, fitnah, intimidasi, mobilisasi massa, persekusi, kekerasan dan pembentukan organisasi-organisasi paramiliter sebagai instrumen gerakan-gerakan totaliter yang digunakan oleh para penganut populisme agama. Fenomena semacam ini sarat dengan manipusi dan kebohongan yang memecah-belah kelompok-kelompok sosial dan melemahkan budaya politik sehingga sulit untuk mencapai konsensus ideologis. Masyarakat biasa atau bahkan kaum intelektual tidak mampu melawan manipulasi dan kebohongan yang terorganisir. Pertaruhannya bahwa populisme agama berisiko membahayakan dasar bangsa Indonesia yang terumus dalam semboyan "Bhineka Tunggal Ika".
\end{abstract}

Kata Kunci: Bangsa; Keberagaman; Patologi nasionalisme; Populisme agama; Totalitarianisme.

\footnotetext{
ABSTRACT

The sustained rise of religious populism across the globe has influenced Indonesian political situation. In Indonesia, the last ten years have witnessed the increasingly widespread emergence of religious populism. Populists express strong moral judgments in decrying corruption, moral decadence, and

${ }^{*}$ Corresponding author: jhmoko59@gmail.com.

Copyright@ 2019 THE AUTHOR (S). This article is distributed under a Creative Commons Attribution-Share Alike 4.0 International license. Jurnal Kawistara is published by the Graduate School of Universitas Gadjah Mada.
} 
corrupted elite in power. They define society in Manichean terms as divided into a good 'us' and an evil 'them'. In defining both of these categories, they put forward the important role of religious identities in order to classify who fits into the category of 'us' and who belongs to 'them'. Hannah Arendt offers sharp analyses allowing to uncover religious populism mechanism. Her main analysis was based on the pathology of tribal nationalism. The result of her analysis helps us to explore the similarities of tribal nationalism pathology and religious populism phenomena. The use of comparative and critical approaches helps to conclude that the pathology of tribal nationalism gives lessons on how such a movement cannot accept differences and tends to be totalitarian. Such a comparison opens new perspectives on helping to examine the phenomena of propaganda, slandering, intimidation, mass mobilization, persecution, violence, and formations of paramilitary forces as instruments for totalitary movements used by religious populism. Such phenomena are loaded with manipulations and lies which have fragmented social groups and weakened political culture so that ideological consensus is impossible. Ordinary citizens, even the intellectual, are not able to oppose well-organized lies and manipulations. The danger is that such religious populism maneuvres risk jeopardizing the foundation of the Indonesian nation, which is formulated under the motto "unity in diversity".

Keywords: Diversity; Nationalism pathology; Nation; Religious populism; Totalitarianism.

\section{INTRODUCTION}

Indonesian political development after The Reforms (1998) has resulted in not only a positive aspect in the form of increasingly wider participation in political decisionmaking but also disappointment with the foundation of the nation's ideology (Pancasila) as it was long abused to maintain the New Order regime's power. As a result, among the people there has grown a skeptical attitude toward Pancasila, which should have guaranteed the values of unity, justice, liberty, and equality before the law. As an apathetic reaction, there have been many obstacles in growing the Pancasila values, which leads to ineffectiveness. Such marasm (skepticism due to the energy deficiency) has opened opportunity for intolerant ideologies to increasingly prosper among the society. The characteristics are rejection of those who show differences, wider spread intimidation, persecution, and violences against certain groups. The concern about such situations has lead me to accept the invitation by the Graduate School of Universitas Gadjah Mada to participate in digging up nationalism, particularly its pathological mechanisms: discrimination and national fragmentation. Hannah Arendt offers sharp analyses on nationalism thanks to her experience and great extent of archival studies. New perspectives help examine the phenomena of propaganda, slandering, intimidation, mass mobilisation, persecution, violence and formations of paramilitary forces as instruments for totalitary movements. The order of the presentation follows the purpose of this article which is determined by its method.

The purpose of this article is to bring into view the latent threats of religious populism against the existence of cultural diversity in Indonesia. The promise of the critical discourse analysis to dismantle the interest or ideology dissimulated behind languages captures many researchers' attention to use such a method. This method is also suitable to explore Arendt's text on tribal nationalism in terms of totalitarian mechanisms. Observing the phenomena of religious populism, there are characteristics which lead me to suspect them as a form of the reappearance of the mechanisms of tribal nationalism previously analyzed by Hannah Arendt. This suspicion actually inspires me to propose a hypothesis in this exploration, namely that there are some similarities of religious populisme phenomena to the mechanisms of tribal nationalism especially in its totalitarian tendencies. Hannah Arendt's analysis has pointedly unmasked the disguised ideology of violence. Nevertheless, the method of critical discourse analysis, especially that of Norman Fairclough's version, helps to sytematically deconstruct a text suspected of being loaded with discriminatory ideology and unjust domination or having a prejudice against 
some groups. This method consists of four stages (N. Fairclough, 2010: 235), which are as follows: stage 1: focusing upon a social wrong, in this case, namely some totalitarian mechanisms leading to religious/ethnic discrimination: all topics focusing on tribal nationalism, its pathology and its totalitarian mechanisms; stage 2: identifying obstacles in addressing social wrong, which consists of rejecting the distinction between State and Nation; behind the mission sacrée, there is an implication of superiority feeling, meaning that the invading nation feels to be the "chosen" one and risks the encouregement of abusive treatments; stage 3: considering whether the social order 'needs' the social wrong. This stage highlights whether the social wrong in focus is inherent to the social order and whether it can be addressed within it, or only by changing it (N.Fairclough, 2010: 238). This stage is well defined by the beginning sentence of the part entitled Pre-totalitarian Movements and Their Strategies: "Under the spread of corruption in all aspects and the decay of bureaucracy, pre-totalitarian movements seem to receive strong winds to maneuver". In other words, the social wrong (the totalitarian tendency and mechanisms of religious populism) "needs" the social structures (the corrupt government and the decay of bureaucracy) because the latter enables religious populism to reign and prevail; and finally, stage 4: identifying possible ways to overcome the obstacles. This last stage involves a semiotic approach consisting of comparing, contesting and criticising the disguised dominant discourse which legitimizes the totalitarian mechanisms as described in the last discussion and systematisized in the conclusion.

\section{Western Nationalism and Tribal Nationalism}

When one talks about nation, usually the association is directly related to E.Gellner's concept. According to the author of the book Nation and Nationalism(1983), which is nationalism experts' main reference, a nation relies on three elements: (i) a nation has the same cultural reference; (ii) nation is a construct of conviction, loyalty, and solidarity of its members; (iii) a nation is built when the members mutually recognize their respective rights and obligations because they have an equal status (1983:7). Different from Gellner, Hannah Arendt has dug deeper from the evidences of nation-states' development history and their negative impacts to communal life. Therefore, this political philosopher distinguished western nationalism from tribal nationalism.

Western Nationalism is manifested in nation-states which claim to represent national societies and sovereignties which have developed since the French Revolution in the 19th century. Its form is a combination of two factors, which should be separated, namely nations and states (Arendt, 1995: 197). "Sociologically, nation states are European political bodies which emancipate the peasant class ... Western nationalism ... is a result deeply rooted in, and is a form of, peasant emancipation" (Arendt, 1995: 197). The combination between states and nations sets out from the French revolution on people sovereignty. Therefore, Arendt always refers to France everytime she defines what a nation really is.

"A new concept of "nation" born from the French revolution (1789) has the following characteristics: first, based on people sovereignty and active agreement to the goverment (le plébiscite de tous les jours) and relies on the existence of a number of uncountable national organizations all of which are sovereign" (Arendt, 1945: 444-445); second, a nation starts recording its history and acquiring emancipation when people reach an awareness of themselves as an entity of culture, history and territory as their permanent dwelling place" (Arendt, 1995: 197).

Meanwhile, tribal nationalism originates from tribalism awareness extended with a commitment to unify those having the same blood or the same spiritual origin (religion) to mark the distinction of "nation" above all others (Cocks, 1996: 41). In Western nationalism, the society development is marked with 
the achievement of self-awareness as a cultural, historical and territorial entity. In Eastern-European countries, such signs of awareness do not emerge in their world of ideas. Therefore, these countries are considered to have failed in building nation-states because, first, they are not deeply and strongly rooted in the peasant class. The peasant class in Eastern European regions tend to bear their own personal interest than common concerns to public civilization (Arendt, 1995: 202). And, second, they do not have states and historical achievement which can serve as their common pride. Their commonness lies more on their languages, and even they rely only on their Slavic or Germanic spirit (Arendt, 1995: 201).

The tendency of the peasants in Central and Eastern European countries to prioritize their own personal interest has produced tribal nationalism which does not easily accept differences, which lead the countries to suppress forms of public manifestation which reveal ethnical-cultural differences in order that the national identity and their citizens' equality can be guaranteed. This attitude means ignoring oppressions to different ethnic or religious minorities (Beiner, 2000: 47). The tendency to oppress public manifestation of ethno-cultural differences, according to Arendt, is caused by two reasons: first, nationalism in Slavic and Germanic states is marked with the distinction of loyalty to the state and loyalty to the nation, which means that the state is no longer considered to represent people sovereignty but as a supra-national bureaucratic machine (Arendt, 1945: 460). The case of the German rule over Czech can be seen as the emergence of the structure of supra-national states because supra-social states of homogeneous nations are assumed to overcome class-struggle gaps (Arendt, 1945: 460).

Second, in Eastern European regions, every region is settled by different mixed ethnic groups so that their weak political represention cannot be compensated with a certain representation form. If only the population were homogenous, a form of representation could be easily organized. Therefore, these peoples have never managed to be rootedly unified with the dwelling place, unlike the Western European nations. As a result, their citizenship cannot be directly related with their settlements because they are fully separated from their countries so that citizenship is a separate value, or with different connotation. The fact that one is born as a German, a Czech or Slovac is more important that the loyalty to the nation state. People no longer think of their common achievements which are able to make historical records. As a result, the emerging national awareness touches only personal virtues and is weak in terms of solidarity. Common achievements cannot be represented as a political organization, while communities cannot provide adequate witness (Arendt, 1945: 461).

The danger of such a condition is that if there is an opportunity which can unite scattered people of the same ethnicity they will be ready to directly join a political adventure and ripe for imperialistic expansion (Arendt, 1945: 462). According to Arendt, the secret of the success of Pan-Slavic and Pan-German movements lied in the support of strong mass base and even chauvinism. Chauvinism emerges from the absence of nationalism trinity (nation-territory-state) which influences the idealism of their desired nationstate. These are militant mass which in fact do not have any idea whatsoever on the meaning of patria, and even they do not have any understanding on the responsibility for their shared community, let alone the experience of political freedom (Arendt, 1945: 462). They are ready to do anything and enthusiastic to join in political adventures (totalitarian movements), which is more than any existing political organizations.

Obviously, the unification movements potentially lead to two dangers. The first is the horrible tragedy of totalitarim movements, and the second is expansionism. Why are they prone to totalitarian movements? There are two triggering factors. The first is the ever-shifting state boundaries, and the second is the ceaseless migration of people. 
The two situations are obstacles for the formation of the three pillars of "civilized" nationalism, namely nation, territory, and state. Nationalism deficient of the three main pillars and without deep roots is called "tribal" nationalism, and subsequently will open fertile grounds for totalitarism (Beiner, 2000: 51). Memory to history, albeit obscure, provides emotional attraction beyond nationalism boundaries. The growth of new nationalism is marked with masses motivated to commit violences because objective data are with less influence than emotion, particularly when dealing with language unity or tribal unity, because the nationalism prioritizes the nation.

\section{Rejecting the Distinction of State and Nation}

The distinction between state and nation determines the fate of the citizens, particularly the minority groups. If the nation changes the state from its being a legal instrument into a national instrument, it leads to discrimination against, and weak protection, for minority groups.

A nation represents an environment where one is part of since birth, which means a closed community because one is part of it due to the inherent rights since birth. Meanwhile, a state is an open community which rules a territory and whose power is meant to protect its people and to make laws.Therefore, as the highest legal entity, a state only knows its citizens without regards their nationality. Therefore, the legal structure is open to all those who happen to live in its territory (Beiner, 2000: 52).

States are not synonymous with nations because the function of states is to be the main legal protection to guarantee peoples and their rights as human beings, as citizens and their rights as nations. Only their rights as humans and citizens are their main rights, while their rights as nations originate from their rights as citizens and the implications (Beiner, 2000: 53).

The tragedy of nations states occurs when the emergence of people's awareness makes them difficult to accept differences. Such closedness of a community component disturbs the main functions of the state, namely to provide protection for all inhabitants in its territory, without regards to their nationality, and to serve as the highest legal institution. In the name of people's will (identical with the majority's), the state is forced to give its political and civil rights fully only to those who are part of the national community on the basis of the rights of origin and the fact of birth. Therefore, the state is changed from being a legal instrument into a nation instrument (Beiner, 2000: 51). Diversity is repudiated because the component considered as the citizen unifier is nationalism which is based on the same origin, while every social class and part of the society is always dominated by interest groups. The national interest is made identical with the interest of the community of the same origin, as if their common origin could serve as a guarantee through sentimentalism which is revealed in tribal nationalism.

Such a concept of nation which robs the state's authority is the reason why Arendt was against Zionism as conceptualized by Theodor Herzl. According to Arendt, Zionism is no different from tribal nationalist politics because its pillars rely on the experience of being part of the same nation, namely the Jewish nation, as the basis of the claim to belong to the same state and nation. Zionist politics is by Arendt considered to choose a political community conception which in fact betrays the main aspiration of the oppressed community (Beiner, 2000: 45). Why is it considered to betray the oppressed community's aspiration?

In its initial emergence in the $19^{\text {th }}$ century, nationalism offered consistent political teaching, namely that nationalism becomes meaningful revolutionary principles for community national organizations. However, nationalism changed into a wicked power when it did not guarantee people's sovereignty and was not able to determine fair relationship to inhabitants living beyond the national boundaries (Beiner, 2000: 45). Thus was the 
fate of Zionism that it was no different from other ideologies (nationalism dan socialism), in the sense of its being a form of distortion to political reality, and Zionism is considered as a sectarian ideology (Beiner, 2000: 45). This nationalistic ideology has been taken over by the Jewish intellectual under the consent of big countries because it has been totally sold to the imperialistic rulers whose ambition was to create a Jewish nation state in the Palestine.

Eventually, the Zionist movement is no longer solidarity with the oppressed nations. The revolutionary spirit inherited from the French Revolution has been sacrificed by Zionist leadership's manipulation (Beiner, 2000: 47). Therefore, the Zionist Movement' leaders are more focussed on the relationship with big countries than the political project to develop trust relationship with neighbouring Arab states. Arendt was against the separation of Palestine from the Jewish state (UN's agreement, 1947) and was against the formation of a Jewish state. He proposed the formation a Jewish-Arab federal state. The Jewish real goal in the Palestine can only be achieved based on the Jewish-Arab cooperation.

Arendt, to guarantee nationalism issues, relies on the federation system. In this federation structure, the status of nationalism will be more than territorial (Beiner, 2000: 53). If it is a personal status, the citizenship issue will be part of the political structure. Then, people are treated as part of a nation in their right position in the public life. (Cf. the level of "political action" in Condition de l'homme moderne). Therefore, Arendt always refers to the French Revolution because since the revolution people are understood as the images of the nation family, and human rights are meant to be deemed universal: people are not individuals but human images (Arendt, 1995: 199).

Human rights must be guaranteed by all governments. In the historical development, countries adopting human rights generally do not acknowledge their universal dimensions. Nation states usually understand them in the national framework, namely as a particular, not universal, community scope. Therefore, it is not suprising that in practice governments often neglect their citizens. As a result, no authority can protect them (the victims are usually minority groups), and no institution can guarantee them (Arendt, 1995: 199). Thus, the issue of human rights cannot be separated from the issue of nation emancipation, which means that only emancipated people sovereignty is capable for guaranteeing them. In fact, liberated (sovereign) people, as represented by the concept of "human" in the French Revolution, are considered abstract, not directly related to inhabitants of a certain place. Meanwhile, sovereign people concretely live in a region and have historical cultural bonds.

A problem arises when human rights for their effective guarantee assume the existence of a state agency. In fact, a state agency usally will protect those who are considered as its own members. Therefore, the loss of rights to be part of a nation leads to the loss of human rights. So is the fate experienced by stateless minorities. The logic for the need of a state agency as the guardian and the guarantor of one's right, for Arendt, obviously does not refer to a tribal nation state. As cited by Beiner, Arendt sees the only way for a state to be a safe haven for its citizens' human rights is by excluding the concept of nation from a nation state (Beiner, 2000: 55). This opinion of Arendt's, according to Beiner, refers to the United States because as a political community it has reached the condition of a state, without taking the form of a nation state but a nation in the federal relation network. A state is not identical with the site of sovereignty. National sovereignty opens the weak side of nationalism as an ideology, namely that it rejects all forms of universality because they are deemed as interference from external elements and, as a result, also reject the universal dimensions of human rights (Beiner, 2000: 55). Such tribal nationalism is not based on nationalistic pride, but it is more a form of rejection of the universal principles of human rights, which tends to be discriminatory 
towards its own nation. Therefore, tribal nationalism is not a form of chauvinism.

\section{DISCUSSION}

\section{Tribal Nationalism was Uprooted from Reality}

Chauvinism has developed from the old idea of the existence of a nation's mission, namely to bring light to other nations deemed less fortunate (Arendt, 1945: 457). Chauvinism is positive because it reflects the development of responsibility for the welfare of developing nations. However, it becomes a problem if behind the idea of this mission sacrée there is an implication of superiority feeling: the invading nation feels to be the "chosen" one.

This concept of being chosen, according to Arendt, destroys the idea of human unity which shares the same divine origin (Arendt, 1945: 458). This sort of attitude risks the encouragement of abusive treatments. Therefore, chauvinism is prone to abuse when it changes into an ideology because chauvinism is deep down in the nationalism which since its onset has marked imperialistic countries (Arendt, 1945: 458). Imperialism which alienates citizens to be far from their own state has alienated nationalism from the state boundaries. However, this chauvinism though marked with the separation of national loyalty is obviously not separated from the loyalty to the state. In this manner, Arendt refers to unification movements (Pan-Slavism and Pan-Germanism) which originates from nation states but she considers states not as people sovereignty representation though the states appear as supra-national bureaucratic machines, whose authorities are in the hands of the ruling institutions (Arendt, 1945: 460).

In the perspective of ignoring the state role, Pan-Germinism emphasized the national priority above the state interest because the only permanent factor in the history is the people not the state (Arendt, 1995: 211). From such an interpretation, the ruler's initial totalitarian nature emerges because by stating that the permanent historical factor is the people it is possible to conclude that the national needs which change in accordance with the situation must always determine the state's political actions (Arendt,1995: 211). The manipulative loopholes lie in the definition of who the people are and who formulate the national needs. These two loopholes are opportunities for the rulers to represent themselves. In contrast with chauvinism, tribal nationalism emphazises too much on the struggle for people's interest and diguises deceitfully its thirst for power. Chauvinisme is oriented to a nation's achievement, so the struggle is focussed on the nation's spiritual and material achievements. This struggle makes chauvinism remain rooted on reality; while tribal nationalism shows more care to what is being thought and what is being felt than what is happenning outside. Thus, it concentrates more attention to itself, which is considered as the manifestation of national quality. Then non-existent semi-mystical elements are deemed to appear in the future (Arendt, 1995: 193).

The manifestation is in the form of arrogance: the ability to measure and to predict the fate of the nation, using the inner quality as a yardstick, disqualifies the existence of the prevailing tradition, insitutions and culture (Arendt, 1995: 193). Such semi-mistic view gives foundations of justification upon political paranoia: the nation is surrounded by a world of enemies, and the the claim that one's people is unique and not part of the human commonness (Arendt, 1995: 194). This claim of uniqueness shows a superioity and serves as an entrance door to get ride of the guilty feeling for having oppressed, exploited and destroyed other nations, groups and ethnicities.

\section{Imperialism as Tribal Nationalism Pathology}

Tribal nationalism which represents itself in unification movements ("Pan-...") uses nations' rights to determine their own fate as its rational basis. This reason is eventually used as a disguise to cover a nation's imperial expansionism (Beiner, 2000: 49). National ideology struggles for the aspiration 
to unify nations of the same origin though they might have different histories or might live in different territories. Such nation states based themselves on primordial unity which is prone to various forms of discrimination. The source of discrimination can be revealed through the explanation of nation state pathology which emphazises on the dichotomy between the good "us" and the evil "them".

According to Hiltler, it is impossible to instinctively do the right thing if our mind ignores the difference between ourselves and the other parties. When two people are drowning and one of them is my brother, what is more logical and morally accountable is prioritizing to save my brother. My brother is part of "us". In the effort to make tight distinction between "us" and "them", the slogan for the SS (Schutzstaffel = Hitler's Protection Squadron): Meine Ehre Heisst Treue (My honor is loyalty) was formulated. It turns out that the basis for the driving force to extremism is not only fanatism. Extremism grows when it manages to get rid of the traditional morals which serve as guidance.

One of the pathological forms in the practical politics, according to Arendt, is that when a nation shows itself as a conqueror it will encourage the growth of national awareness and desire for sovereigncy among the conquered (Arendt, 1945: 45). Thus, the imperialistic tendency is inherent in nationalism ideology because conquest is a permanent method to rule. A state system which denies its imperialistic nationalism will open doors to totalitarism movements to accomplish the task to destroy the core of nation-state ideas. Nation states which should provide protection to their citizens and guarantee respects to the rights of other nation states for doing the same eventually disrepect their own main task (Beiner, 2000: 50).

Nation states are willing to destroy other states which are the safe havens for their citizens, morally and legally (Beiner, 2000: 50). In this way, the dream for nation purification no longer faces any obstacle. Nationalism is not free from citizenship pathology because the desire to make states subject to the ideas of nations. As a result, nationalism is more identical with expansionism which goes beyond state boundaries, including the moral boundaries. To get rid of the guilty feeling that moral boundaries have been ignored, a sophisticated scientific justification is used, namely distinguishing between ethics and morals.

Dealing with such nationalism pathology, I would like to point out three remarks. Firstly, we can investigate how and from where the cruelty or heartlessness derives. The distinction made by Avishai Margalit between ethics and morality (Manus I. Midlarsky, 2011: 343) helps to clarify that source of violence. "Ethics" is obligation which emerges from thick relations (family, nation), so what is at stake for ethics is more related to loyalty and betrayal. Meanwhile, morality is obligation in thin relations, not of the same family or the same nation). What is at stake in morality is respect to, or humiliation for, others. Hitler's ingenuity in changing universal moral norms to be fully relevant to Germany is ethics. The focus is demanding the citizens' loyalty because it is the result of thick relations which involve fellow Germans.

Traditional morals are considered as motivation for obedience to universal morals in the forms of empathy and sympathy and they must be opposed because they restrain group fanatism. The more anonymous or alient the victim is, the more violent the treatment will be, and only empathy and sympathy can restrain people from being heartless or cruel. Therefore, the above distinction between ethics and morals is part of the systematic process to get rid of the obstacles. That is why Nazism adherents can arbitraryly commit violence against Jews and other nations in with apparent impunity and without any guilty feeling. Secondly, the above distinction also hides the guilty feeling of the imperialistic politics of tribal nationalism, even though imperialism is in fact used to solve problems of internal conflicts and disintegration threats. An archive found by Arendt showed that all governments know exactly that their countries are in a disinte- 
grating situation, that the political body is being destroyed from the inside, and that their life is in borrowed time (Arendt, 1945: 450). So imperalism is driven by the conviction that the national body itself is deeply divided into classes so that class struggle is a symptom of modern political life. Native citizens often disrespect naturalized citizens, who receive their rights from legal procedures, not from being born in the country (Arendt, 1995: 200-201). It can be imagined how fragile is the nation cohesion in such a discriminative situations. Therefore, territory expansion can be a savior as long as it can be a common cause as a nation (Arendt, 1945: 454). Common challenges outside the nation body can help people cohesion and can avoid fragmentation into social classes.

Thirdly, honest people can actually still put their hope on a layer of people purposefully created in order not to be partial to certain classes. This layer of people who provide public service is the body of permanent public officials. They are supposed to serve citizens without regards to their class/group and do not depend on government change. The motto of public servants must be honor and self-respect deriving from their position as public servants. However, the independence of the public servants very much depends on the economic independence and political neutrality. When a nation starts rotting by public servants' corruption, their neutrality is doubted. The corruption and the decay of public servants make people skeptical and this opens doors to political adventurer demagogues to create ripe conditions for the emergence of totalitarism.

\section{Pre-Totalitarian Movements and Their Strategies}

Under the spread of corruption in all aspect and the decay of bureucracy, pre-totalitary movements seem to receive strong winds to maneuver (which can be in the form of religious populism). Under the disguise to bring back power to the people, pre-totalitary movements press the rulers. In the condition of global economic ucertainty, unemploy- ment, and injustice, pre-totalitary movements promise economic fairness and brotherhood through moral revolution. These movements criticize the government and democracy because the government should be the mirror of people's will, but people's sovereignty has been confiscated and exploited by the rotten elite. Political weapons in the form of disinformation with propaganda and message engineering techniques to arouse emotion are used to shut down people's critical ideas and to create fragmentation. Indeed, these pre-totalitary movements are very skillful in using strategies.

The pre-totalitary movements' strategies include the following. The first is using propaganda and intimidation as mass persuasion instruments. The second is engineering information to confuse people in interpreting realities. The third is engineering conspiratic tactic management by creating suspicion and hostility among groups. The fourth is discrediting enemies with slander and character assasinization, particularly through sensitive issues (religious offenses), and the fifth is creating political myths.

All propaganda techniques which arouse emotion are used to draw people's attention, including the elite's, to the totalitary spirit. Through propaganda, the offered discourses must receive public sympathy. All these strategies are used to snatch power because political demagogues are skillful in taking the opportunities offered by a regime which guarantee freedom of speech. If necessary they use terror and intimadation as long as these do not make the state apparatuses take actions (Arendt, 1972: 67). Like other parties, they recruit followers and maintain their sympathic public image and always show pro-people political attitudes.

In its development, when they have secured the power control, they will replace propaganda with indoctrination. Violence is used only to deter people (Arendt, 1972: 67). Propaganda are part of the psycho war, while terror is the essence on which such a regime is based to achieve their psychological aim, namely people's total obedience (Ar- 
endt, 1972: 69). Therefore, initially intimidation and terrors are used limitedly, but with the development of time, they are used more widely without fear to the legal enforcement apparatuses. Both the police and the justice courts are afraid of taking actions and seriously processing the crimes commited by "the rightists". Intimidation and terrors are very precious because they are forms of propaganda to show how powerful they are (Arendt, 1972: 70).

Movements leading to totalitarism usually use racism (and possibly religious discrimination too) to unify their mass groups in order to be more militant. It starts with qualifiying leaders as infallible (Arendt, 1972: 74). In order for racism to be able to mobilize the mass, the leaders must gain total support, particulary in their public communication. The success of public communication lies in the ability to convince the mass that the leaders are infallible. Usually, self-fulfilling prophecy is used as a means, even as a habit, to declare the political intention in the form of prediction. The most wellknown example was when Hitler in front of Reichstag (January 1939) declared: "Today, I would like to present my prediction: If the Jewish financial managers once again succeeds in pushing people to a world war, the results will be the destruction of European Jewish race". If translated into political language, "I will make wars and kill European Jews" (Arendt, 1972: 75). Such a predictions serves as a retrospective alibi that none can happen without earlier prediction. People just agree what the leaders predict and believe that eventually it will happen. In fact, the prediction is part of the planned political program.

The main weakness of totalitary propaganda lies in its inability to satisfy the public desire that their vision of the world should be coherent, understandable and predictable and not against the common sense (Arendt, 1972: 78). The problem is that critical thought and the common sense will easily uncover propaganda lies. Therefore, in order to make their world vision coherent, totalitory ideology followers are voluntarily willing to be up- rooted from reality. For example, two neigbors live together without conflicts. When one of them is told by his religious teacher that the mirror of true believers is not socializing with people of a different religion, then he willingly ends the good relation with his neighbor. He is uprooted from the reality of good neighbor relation.

Aspiration which ignores reality becomes the ideology followers' obsession so that, according to Arendt, the mass are so obsessed to desire to get rid of reality because they can no longer stand the accidental aspect which cannot be understood with reason 1972: 79). All must be predictable; and, if not in accordance with the prediction, violence should be used to make them happen. Therefore, the uprooting must be compensated with ideological justification: metaphysical ideological justification which is full of lies becomes the answer. Individuals in the mass are solitary, isolated and atomized, so critical opposition is impossible. Rejection to realism, common sense, and rational world view are no more than the results of mass atomization and the loss of their social status. They even loss their normal relation with their daily community, while in fact it is the community which allows them to use their common sense (Arendt, 1972: 79). Alienation from daily reality is the price to pay for joining the movement of the more just new world under the utopist teachings of their leaders.

To guarantee the obedience to their leaders and their teachings, a paramilitary group is founded as an instrument for the struggle of their movement's ideology (Arendt, 1972: 97). The foundation of this paramilitary originates from the totalitary logic which allows to always create a new layer in their organization in order to define their militancy levels (Arendt, 1972: 96), so the paramilitary members are trusted to safeguard the movement's ideology. Before securing power, totalitary movements always present a world which is so full of lies, even which are so reasonable that they are beyond reality, in order to satisfy the human spiritual thirst. One of them is creating fiction. The most effective fiction 
of Nazisme was the propaganda which engineered the existence of the Jewish conspiration all over the world (Arendt, 1972: 80-81).

\section{Anti-Jew Mistification as Mechanism of Scapegoat Pointing}

Nazism used anti-semitism as an important political weapon to cover their terrors and violences under the disguise of opening new civilization and building up a new political body (Arendt, 1995: 156). To define Jews as Aryan people's enemies is a way to justify whatever they did, including violences and murders. The logic of violence which topped up with ethnic cleasing was based on three mechanisms, exactly like what Hitler did: scapegoat pointing, conflict radicalization, and group purification by destroying enemies. In fact, hatred arose from the suspicion on the clandestine relation between Jewish communities and European nation-states: the Jews were accused as oppressive state apparatus agents, and, even more, foreign oppressors (Arendt, 1995: 195-196).

Initially, the hatred to Jews was based on the real experience in directly seeing the Jews' life in economic, social, and political fields (Arendt, 1995: 197). Only later, legitimation was sought from racism ideology and xenophobia (anti-foreigner feeling). For example, Schoenerer, a pioneer of Austrian Pan-Germanism, saw the relation between the Habsburg monarchy and the Jewish businessman Rotschild's role in the railway system in Austria (Arendt, 1995: 196). The domination in the economic life produced social suspicion as injustice. Psychologically, social gaps produced insecurity, which led to the feeling of uselessness. This feeling of uselessness was used by demagogues to provoke anger and hatred. What was waited for was a trigger to arouse social emotion which could lead up to violence.

The seeds of hatred which grew from the experience was strengthened by the presence of "spreading awareness of tribalism" which served as the emotional motor for Pan-Slavic and Pan-Germanic movements. Pan-Slavism began becoming anti-Semitism in the end of the 19th century as seen in the following illustration (Arendt, 1995: 213-214): Schoenerer with his anti-Semitism was able to see the opportunity to destroy Habsburg Empire. Adolf Stoecker, a Protestan minister in Berlin, through his anti-Jewish sermons and lectures was able to draw sympathy from small vendors, artisans, and low-level employees marginalized by industrialism though he could not compete in influencing socialist labour associations. Anti-Jewish antipathy also dominated all Russian intellectual circles so that after the Tzar assassination in 1881 there happened waves of mass persecution and mass murder against the Jews (Progrom).

The Nazi movement made anti-semitism effective and not remain only as a propaganda because it managed to package it by joining it in the "tribal" nationalism. The concept of "nation" as a superior race Nazi movement is similar to the concept of the Jews' "being chosen", which has made this "chosen pople" have a deep root and divine legitimation. This similarity is in fact a form of rivalry which produced jealosy which then changed into hatred.

The Jews are an example of a people, according to Arendt, without any land, but have been able to maintain their identity for centuries. This is a proof that neither territory nor institution is needed to build a nation. Similarly, Nazi movement subordinate the importance of the state in order to prioritize people who are organized without the need of being represented by observable institutions. The Jews' pride as part of the chosen people, without regard to their achievement or tradition, shows how Judaism has deeply rooted in any Jewish individual. The same was in fact tried to be planted by "tribal" nationalism, namely their being chosen as a superior race as the Aryan people was expected to make Germans believe that the psychological, physical, or ethical competences were inherent in Germanism (Arendt, 1995: 216-217).

From the perspective of the mimetic theory (R.Girard, 1982), in my opinion, it can be easily explained. Hitler's ambition to convince the Germans as a superior people was 
in fact a growing ambition because the salvation history labels the Jews as the "chosen" people. However, those who helped growing this ambition in their turn became an obstacle for its realization. Therefore, the Jews must be eliminated. The concept of the Jews as the chosen people was a form of religious identification with their nationality. Similarly, religious populism assumes that nationalism should represent the bonds of emotional cohesion among the same religion's adherents because religion is considered as the bearer of God directly to the earth. The Jewish claim in their historical position of having a special relation with God brought to the Western civilization the element of fanatism which of course creates competition, jealosy and, eventually hatred. Such fanatism inspires extremists to suppress the cultural diversity because their ideals are not liberty and equality. They tend to oppress the minority groups. Zionists has been to oppress the Palestinian people.

As stated by Joan Cocks, for Arendt liberty is understood more as an ability to start something new in the world. This understanding is related to one of human action weaknesses, namely being unpredictable (unpredictable in terms of the directions, impacts, results and consequences). Based on the series of unpredictable actions, which they cannot control, it is possible that all 'selves" are independence who determine themselves in their independence (Cocks, 1996: 46). I would like to remark upon Arendt's definition of liberty. As an ability to start something new in the world, liberty requires the human ability to transcend oneself and to free oneself from determinism or the cause-effect law. This requirement helps people not to fall into a trap of retaliation. Even when facing an opposing political entity, a social movement inspired by such liberty will not be tyranical against its own minority. This virtue is not separated from the understanding of "self". Misunderstanding the concept of "self" is a source of exclusive tendency.

In the logic of self-determination, "self" is understood as particular (people of the same nation originate from the same race or religion), not universal (all those who stay in a country are recognized and protected by law because of their acceptance of the law). "Self" also has material devices to impose one's will on others (Cocks, 1996: 45). In my opinion, religious populism is dangerous when, because of the strong impact of ideological legitimation, the concept of "self" is made identical with followers of the same religion. Then, struggles for self-determination change into attempts to dominate and discriminate fellow citizens. Is it not from here that the danger of religous populism emerges?

\section{Religious Populism: A form of Tribal Nationalism Pathology?}

Populism is a form of reaction to the disfunction of democracy. This accusation is directed to ruling politicians because they are deemed "not to run power for the people's interests". Religious populism is similar to pre-totalitary movements in two aspects. First, it is a kind of a flag for the struggles to defend people under the reason that people sovereignty is confiscated by the corrupt elite who are not sensitive to the people's interests. Usually, the critics are also addressed to demagogues who are thirsty for power: their behavior is the same when in power, but to get sympathy they need to show partiality to the people.

Second, populism is good at using demagogy and rhetorics. They know exactly the core of ommunication is to aim at influence through manipulation. They always try to find ways how negative prejudice can be intensified by manipulating the people's emotion for fragmentation purposes. Demagogues lend their voice to the people. Their characteristics are as follows. First, they are able to adapt themselves with the people emotional situation by showing various faces as many as the people's social categories. Second, their principle is "To persuade means to die as a reality in order to produce tricks" (Berlinguer in: J. Baudrillard, Simulacres et Simulation, 1981: 32-33)). Third, they 
are willing to touch the people's emotion by subordinating facts and objectivity or rationality. Demagogues are willing to engineer collective emotion by relating crises with mass traumatism by putting themselves as victims of injustice or objects of humiliation. This means is effective to intensify hatred. Furthermore, demagogues are good at using metaphors rooted in the culture, history, and religion of those whose emotion is to arouse.

Third, religious populism, according to Georg Betz and Carol Johnson (in Marzouki, Saving the People, 2016: 3) offers seemingly interesting programs, namely claiming to have answers to three problems. First, what is wrong or not right in the society? Second, who is wrong? And third, what must be done to remedy the situation? However, populist discourses tend to raise tension and hostility because the core point is to grab power. It will be more dangerous when religion is made as social capital in this effort. Why is religous populism captivating?

Religious populism can serve as an ideology to give symbolic legitimacy to conquer the public space. The success key for religious populism lies in its ability in three aspects. First, it can provide certainty in the uncertainty of global economy, unempolyment and injustice, it promises economic fairness, and it promises genuine brotherhood through moral revolution. Therefore, religious populism provides a certain identity, namely belonging to a group which promises social stability, status, life view, ways of thinking, and ethos. Religion gives not only promises but guarantees though not based on analysis since it is only based on conviction. This conviction gives certainty.

Second, religion develops conviction that people are in contact with the deepest meaning in life. Third, reference to the final destination of life provides justification and critical attitudes to the social structures rejected (Haryatmoko, 2010: 94-95). Based on the positive points of religions, demagogue politicans cunningly manipulate religion to offer new collective imaginaries to replace crisis-striken imaginaries.
The strength of imaginary rhetorics is its power to change the collective restlessness into fear of dangerous enemies. The efforts to channel restlessness to enemies (scapegoats) already answer traumatism because imaginary rhetorics can explain where the threat is from. Hence, hatred grows. It is fertilized by militants to create desire to destroy all new imaginary obstacles. By destroying the other parties (scapegoats), the feeling of being in power is renewed (Haryatmoko, 2010: 96). The scapegoat is labelled as "the foreign party".

The social imaginary rhetorics of religious populism is similar to the myths created by totalitarism (Nazism and Bolchevisme) to compensate the absence of state, territory and real public life as ideally described. The way is by referring to past glory such as "Holy Roman Empire". Memory to history, despite its being obscure, provides emotional attraction. By offering such myths, the mass is motivated to commit violences for protecting their ideology because the objective fact is less influencial than emotion.

Religious populism engineering which is similar to Pan-Germanic anti-Semitic mechanisms is the allegation and wide-spread propaganda that a foreign party ("not part of our people) is the source of the present problems and crises. Populism is similar in adopting a totalitary strategy, blaming a "scape goat" to unify the mass to be the targets of social emotion resulting from economic discrepancies and the production of massive, planned, engineered and wide-spread lies.

Lies have strong impacts in creating public policies: they destroy public trust to the government. Lies shift arguments to irrelevant problems and delay the law making process for years until arguments can be scientifically solved. Lies fragmentize social groups and weaken political cultures so that ideological consensus becomes impossible. Ordinary citizens, even the intellectuals, are not able to oppose well-organized lies. It is not rare that academicians are recruited to give scientific legitimacy to their engineering. How sophisticated corporations and ide- 
ological interests are in manipulating media for creating a situation where truth cannot be found. To be more exact, the issue of truth is no longer relevant.

The problem is that lies do not emerge as accidents or self-defence mechanisms but designs which are purposefully created, developed, introduced, and engineered for public discourses. Lies are part of coordinated strategic attacks to hide truth, disturb the public by creating conflicts which initially do not exist, whose objective is to stop advances in the common life. In that way, lies destroy ideal democracy by prohibiting authorities from taking care of public interests because they have to face wicked conspiracies among lobby industries, by-order media, opportunistic experts and cunning think-tanks.
By the opportunists, lies are made as strategic infrastructure supported by many circles paid especially to manipulate public policies. They know exactly that well-ordered lies are effective obstacles to stop certain political policies. Lies are more destructive than lobbies for stopping bills or regional election candidacies. The strategic goal is to stop the progress of the solution for the problem which they oppose for the sake of money or ideology. That is why lies, propaganda and character assasination are always used as instruments of mass persuasion, which is part of the similarities between tribal nationalism and religious populism. The detailed similarities between tribal nationalism and religious populism are elaborated below.

Table 1

The Comparison between Tribal Nationalism and Religious Populism in terms of Totalitarian Mechanisms

\begin{tabular}{|c|c|c|}
\hline MECHANISMS & TRIBAL NATIONALISM & RELIGIOUS POPULISM \\
\hline 1. SETTING GOAL & $\begin{array}{l}\text { 1. Its committment is to unify those } \\
\text { having the same ethnicity to mark } \\
\text { the distinction of "nation" above all } \\
\text { others }\end{array}$ & $\begin{array}{l}\text { 1. It offers outwit programs: claiming } \\
\text { to have answers to three problems: } \\
\text { a.What is wrong in the society? } \\
\text { b.Who is wrong? c. What must be } \\
\text { done to remedy the situation? }\end{array}$ \\
\hline $\begin{array}{l}\text { 2. GROUP INTEREST } \\
\text { AND CLAIM }\end{array}$ & $\begin{array}{l}\text { 2. The tendency to prioritize their own } \\
\text { ethnic/racial group interest does } \\
\text { not easily accept differences. This } \\
\text { group-centered interest will lead the } \\
\text { country to suppress forms of public } \\
\text { manifestation which reveal racial and } \\
\text { cultural differences. }\end{array}$ & $\begin{array}{l}\text { 2. It claims to defend people under } \\
\text { the reason that people sovereignty } \\
\text { is confiscated by the corrupt elite } \\
\text { who are not sensitive to the people's } \\
\text { interests. In fact, showing partiality } \\
\text { to the people is a tactic to draw their } \\
\text { sympathy }\end{array}$ \\
\hline 3. RHETORIC & $\begin{array}{l}\text {.Totalitarian movement is keen on } \\
\text { engineering information to confuse } \\
\text { people in interpreting realities and } \\
\text { on engineering conspiratic tactic } \\
\text { management by creating suspicion } \\
\text { and hostility among groups }\end{array}$ & $\begin{array}{l}\text { 3. Populism is good at using } \\
\text { rhetorics. They know the core of } \\
\text { communication: influencing through } \\
\text { manipulation. They find ways how } \\
\text { negative prejudice can be intensified } \\
\text { by manipulating the people's emotion } \\
\text { for fragmentation purposes. }\end{array}$ \\
\hline $\begin{array}{l}\text { 4. THE STATUS OF } \\
\text { STATE }\end{array}$ & $\begin{array}{l}\text { 4. The state will be changed from being } \\
\text { a legal instrument into a nation } \\
\text { instrument in terms of the dominant } \\
\text { ethnic group's interest }\end{array}$ & $\begin{array}{l}\text { 4. The state will be changed from being } \\
\text { a legal instrument into a nation } \\
\text { instrument in terms of the interest of } \\
\text { the dominant religion's community. }\end{array}$ \\
\hline $\begin{array}{l}\text { 5. AGAINST } \\
\text { UNIVERSAL } \\
\text { MORAL }\end{array}$ & $\begin{array}{l}\text { 5. Hitler's ingenuity in changing univer- } \\
\text { sal moral norms to be fully relevant to } \\
\text { Germany is the ethics for demanding } \\
\text { the citizens' loyalty: it is the result } \\
\text { of strong relations among fellow } \\
\text { Germans. }\end{array}$ & $\begin{array}{l}\text { 5. Rejecting the universal principles } \\
\text { (empathy and sympathy). These } \\
\text { principles must be opposed because } \\
\text { they restrain group fanatism. }\end{array}$ \\
\hline
\end{tabular}




\begin{tabular}{|c|c|c|}
\hline MECHANISMS & TRIBAL NATIONALISM & RELIGIOUS POPULISM \\
\hline 6. STRATEGIES & $\begin{array}{l}\text { 6. Its strategies are spreading } \\
\text { propaganda and intimidation as } \\
\text { mass persuasion instruments and } \\
\text { discrediting enemies with slander and } \\
\text { character assasination, particularly } \\
\text { through sensitive issues (economic } \\
\text { exploitation by Jews), and creating } \\
\text { political myths. }\end{array}$ & $\begin{array}{l}\text { 6. Its strategies are spreading } \\
\text { propaganda and intimidation as } \\
\text { mass persuasion instru-ments } \\
\text { and discrediting enemies with } \\
\text { slander and character assasination, } \\
\text { particularly through sensitive issues } \\
\text { (religious offences), and creating } \\
\text { political myths. }\end{array}$ \\
\hline $\begin{array}{l}\text { 7. SCAPEGOAT } \\
\text { POINTING }\end{array}$ & $\begin{array}{l}\text { 7. The logic of violence which topped } \\
\text { up with ethnic (Jews) cleasing } \\
\text { was based on three mechanisms: } \\
\text { scapegoat pointing, conflict } \\
\text { radicalization, and group purification }\end{array}$ & $\begin{array}{l}\text { 7. The logic of violence is based on three } \\
\text { mechanisms: scapegoat pointing } \\
\text { (non-indigenous inhabitants), conflict } \\
\text { radicalization, and excluding other } \\
\text { religions' members }\end{array}$ \\
\hline $\begin{array}{ll}\text { 8. REJECTION TO } \\
\text { REALISM }\end{array}$ & $\begin{array}{l}\text { 8. Rejection to realism and common } \\
\text { sense are no more than the loss } \\
\text { of their social status. The logic of } \\
\text { violence prevails against those } \\
\text { who are not members of the same } \\
\text { ethnicity. }\end{array}$ & $\begin{array}{l}\text { 8. Rejection to realism and common } \\
\text { sense are no more than the loss } \\
\text { of their social status. The logic of } \\
\text { violence prevails against those who } \\
\text { are not members of the same religion. }\end{array}$ \\
\hline 9. ROLE OF MEDIA & $\begin{array}{l}\text { 9. The movement tries to monopolize } \\
\text { the mass media in order to persuade, } \\
\text { manipulate and indoctrinate the } \\
\text { people. }\end{array}$ & $\begin{array}{l}\text { 9. It uses social media to create and } \\
\text { cunningly disseminate their opinions } \\
\text { through hoaxes and manipulations } \\
\text { in order to stir up the social emotion } \\
\text { and skepticism. }\end{array}$ \\
\hline 10. TYPE OF SOCIETY & $\begin{array}{l}\text { 10. Modern society marked by the } \\
\text { second industrial revolution and } \\
\text { consumerism }\end{array}$ & $\begin{array}{l}\text { 10. Information society marked by digital } \\
\text { communication and network society }\end{array}$ \\
\hline
\end{tabular}

The above comparison shows that only two kinds of mechanisms (the role of media and the type society) which firmly distinguish religious populism from tribal nationalism, but these differences are not the determinant factors for totalitarian movement. I notice the nuance of the formulation of both movements' goal. The tribal nationalism is committed to unify those having the same ethnicity to mark the distinction of "nation" above all others. It goes without saying that religious populism has the similar goal, namely to unify those having the same religion. Only the media function changes drastically due to the digital communication. The deontology of journalism does not prevail any more: everyone is a producer of information and opinion. Under the semantic umbrella of post-truth, people disseminate hoaxes, lies, fake news without any guilty feeling.

By observing the organization of systematic production of lies (similar to the Nazism pre-totalitary phase), it is difficult to organize efforts to fight hoax production. The modus operandi leads to the situation where almost no more debate on public policy is possible without the influence of false data manipulated and spread by paid political operators. These politic communication chiefs' modus operandi is very sophisticated, which makes it difficult to prevent, or even to detect in their initial operation though their research centres and organizations are of low quality. With the phenomenon of massive hoaxes, on one hand, many people are made skeptical about the mass media credibility. On the other hand, hoaxes show that people are indeed easy to believe in various social media information. People are conditioned to ignore verification of truth. News, message, and opinion credibility is often not questioned anymore. Lies secretly creep in easily through people's confusion in making distinction among news, opinion, facts, and analyses. As a result, in the ideology-polarized Indonesian society, tension and conflicts can be easilty triggered.

Worse still, hoaxes fertilize social polarization futher because they strengthen each 
group's conviction/ideology. Each group tends to reject any form of different analysis though reasonable and objective. Lies fertilize ideology. Why are lies captivating? It is because liars, according to Arendt, speak using the logic and the expectation of the deceived (1972). This thesis of Arendt's is similar to the logic of hoaxes which try to satisfy the audience's conviction. Hoaxes are the true children of the Post-Truth era. The PostTruth, which according to J.A. Llorente (2017) is "a social-political climate where objectivity and rationality let emotion or desire side with conviction though actually facts show something different" (2017: 9). Where is the post-truth newness in comparison to totalitarism lies?

There are six novelties marking the PostTruth era: (1) the wide access to information content due to communication digitalization, (2) the possibility for people to produce information through social media; (3) media and journalism democratization which allows citizens to compensate public disatisfaction to mass media information and disappointment with politics; (4) people's greater proneness to receive wrong information_due to the development of same-ideology communities with the same conviction; (5) truth-disrupting technology because virality is deemed more important than information quality and ethics, and (6) the absence of falsification or denial of truth but truth is not the most important. People even do not use the term "lie" but "alternative truth" and hoax.

\section{CONCLUSION}

In the Post-Truth era, choosing which should be said seems like only choosing which one is more comfortable, no longer loaded with moral responsibility. All is done for the sake of self-image in front of other people, particularly one's group. The tendecy to lie shows that in political and moral matters humans are basically more groupish than selfish (Haidt, 2012: 97, 203). People pay more attention to their group. The tendency to side with their group explains where group fanatism comes from.
Lies have fragmented social groups and weakened political culture so that ideological consensus is impossible. Ordinary citizens, even the intellectual, are not able to oppose well-organized lies. Academicians have been recruited to provide scientific legitimacy for politicians' engineering. For grabbing power, media is manipulation to create situations where truth is no longer relevant. Finally, what is dangerous is that the newness is utilized for political purposes: to engineer intensification of social groups' negative prejudice through the manipulation of their emotion. In the Post-Truth era, the ethics of politics has no echo any more. That is why religious populism has become more dangerous in the hands of wicked politicians.

Why does religious populism jeopardize the foundation of the Indonesian nation, which is formulated under the motto "unity in diversity"? There are seven reasons which serves as answers to that conclusive alarming question.

Firstly, the similarities of religious populism to tribal nationalism help to reveal its disguised committment, namely to unify those having the the same religion to mark the distinction of "nation" above all others. Diversity is repudiated because the component considered as the citizen unifier is nationalism based on the same religion.

Secondly, the tendency of religious populism to prioritize their own religious group interest tends to ignore differences. This groupcentered interest risks to suppress forms of public manifestation which reveal religiouscultural differences. As a result, the national identity and the citizens' equality cannot be guaranteed. The emerging national awareness touches only privileged-group virtues and is weak in terms of solidarity. Such closedness of a community component disturbs the main functions of the state, namely to provide protection for all inhabitants in its territory, without regards to their religion.

Thirdly, in the name of people's (= the majority's) will, the state is forced to give political and civil rights fully only to those who are categorized as part of the national 
community on the basis of the rights of the dominant religion. Therefore, the state will be changed from being a legal instrument into a nation instrument. The national interest is made identical with the interest of the dominant religion's community.

Fourthly, exclusivism grows when it manages to get rid of the universal morals which serve as guidance. Universal morals are considered as motivation for obedience to universal principles in the forms of empathy and sympathy; and, hence, they must be opposed because they restrain group fanatism. Therefore, the more they exclude other groups, the more the latter become unknown, anonymous or alien. The more anonymous or alien the victim is, the more violent the treatment will be. Only empathy and sympathy can restrain people from being heartless or cruel.

Fifthly, religious populism as a movement and tribal nationalism possess a similar tendency. The tendency of such monolitic groups to grow as pre-totalitary movements is manifested in their strategies of engineering information to confuse people in interpreting realities, engineering conspiratic tactic management by creating suspicion and hostility among groups, using propaganda and intimidation as mass persuasion instruments; discrediting enemies with slander and character assasinization, particularly through sensitive issues (religious offenses), and creating political myths. Unfortunately, movements leading to totalitarism usually use racism or possibly religious discrimination to unify their mass groups in order to be more militant.

Sixthly, the lack of critical thoughtd makes people fanatic adherents of a populist ideology. Aspiration which ignores reality becomes the ideology followers' obsession. People can no longer stand the accidental aspect which cannot be understood with reason. All must be predictable; and, if not in accordance with the prediction, violence should be used to make them happen. Therefore, the uprooting from reality must be compensated with ideological justification which takes the shape of metaphysical justification. Individuals in the mass are solitary, isolated and atomized, so critical opposition is impossible. As a result, rejection to realism and common sense are no more than the loss of their social status. They even lose their normal relation with their daily community, so the logic of violence prevails against those who are not members of the same religion. The logic of violence which is topped up with ethnic cleasing was based on three mechanisms: scapegoat pointing, conflict radicalization, and group purification by destroying enemies.

The seventh is the manipulation of spreading suspicion among the public in facing socio-economic problems. The domination of economic life produces social suspicion and thus considered as injustice. Psychologically, social gaps produce insecurity, which leads to the feeling of uselessness. This feeling of uselessness is used by demagogues to spread suspicion and to provoke anger and hatred. What is waited for is a trigger to arouse social emotion which could lead up to violence. Demagogues' maneuvre to convince the people that they are victims of economic injustice is in fact a scapegoat pointing mechanism. This mechanism allows them to blame the wrong-doing or injustice of some ethnic group. In its turn, the latter is deemed to be an obstacle for the realization of a just society. Therefore, such a group must be marginalized or even eliminated. Such a mechanism may stem from a particular understanding of "self". "Self" also has material devices to impose one's will on others. It is dangerous when the concept of "self" is made identical with followers of the same religion because of the strong impact of ideological legitimation. Then, the struggles for creating a just society change into attempts to dominate and discriminate fellow citizens.

\section{BIBLIOGRAPHY}

Arendt, Hannah. 1972. Les Origines du totalitarisme: Le système totalitaire, translated by Jean-Loup Bourget, R. Davreu and P. Lévy, Paris: Seuil. 
1995. Asal-usul Totalitarisme: Imperialisme. Volume II, translated by A. A. Nugroho and J.M. Subijanta, Jakarta: Yayasan Obor Indonesia. Imperialism, Nationalism, Chauvinism. The Review of Politics, 1945. Cambridge University Press for University of Notre Dame on behalf of Review of Politics, 7(4): 441-463. Imperialist Character. The Review of Politics 1950. Cambridge University Press for University of Notre Dame on behalf of Review of Politics, 12(3): 303-320.

1961. Condition de l'homme moderne, translated from English by George Fradier, Paris: Calman Lévy. . 1972. Du mensonge à la violence (Crises of the Republic), translated from English by Guy Durand, Paris: Calman Lévy.

Baudrillard, Jean, 1981. Simulacres et Simulation, Paris: Gallilée.

Beiner, Ronald. 2000. "Arendt and Nationalism", in Dana Ricahrd Villa (ed.), Cam-bridge Companion to Hannah Arendt, Cambridge Massachusetts: Cam-bridge University Press, pp. 44-62.
Cocks, Joan. 1996. On Commonality, Nationalism, and Violence: Hannah Arendt, Rosa. Luxemburg and Frantz Fanon. In Women in German Yearbook, 12:39-51. (http://about.jstor.org/terms).

Fairclough, Norman. 2010. Critical Discourse Analysis. The Critical Study of Language, Edinburg: Longman.

Gellner, Ernest. 1983. Nation and Nationalism. Ithaca: Cornell University Press.

Girard, René, 1982. Le bouc émissaire, Paris: Grasset.

Haidt, Jonathan. 2012. The Righteous Mind: Why Good People are Divided by Politics and Religion, New York: Vintage Books.

Haryatmoko, 2010. Dominasi Penuh Muslihat: Akar Kekerasan dan Diskriminasi, Jakarta: Gramedia Pustaka Utama.

Llorente, José Antonio. 2017. The Post-Truth Era: Reality vs. Perception. Uno Magazine. 27 March 2017, p. 9, www.Uno-Magazine.com.

Marzouki, Nadia (ed.) 2016, Saving the People: How Populist Hijack Religion, Oxford: Oxford University Press.

Midlarsky, Manus I. 2011. Origins of Political Extremism: Mass Violence in the Twentieth Century and Beyond. Cambridge: Cambridge University Press. 